\title{
Candida species in community-acquired pneumonia in patients with chronic aspiration
}

Benjamin J. Moss ${ }^{1,2}$ and Daniel M. Musher ${ }^{1,2^{*}}$

\begin{abstract}
Background: When Candida species is found in a sputum culture, clinicians generally dismiss it as a contaminant. We sought to identify cases of community-acquired pneumonia (CAP) in which Candida might play a contributory etiologic role.

Methods: In a convenience sample of patients hospitalized for CAP, we screened for "high-quality sputum" by Gram stain (> $20 \mathrm{WBC} /$ epithelial cell) and performed quantitative sputum cultures. Criteria for a potential etiologic role for Candida included the observation of large numbers of yeast forms on Gram stain, intracellular organisms and $>10^{6} \mathrm{CFU} / \mathrm{ml}$ Candida in sputum. We gathered clinical information on cases that met these criteria for possible Candida infection.
\end{abstract}

Results: Sputum from 6 of 154 consecutive CAP patients had large numbers of extra- and intracellular yeast forms on Gram stain, with $>10^{6} \mathrm{CFU} / \mathrm{ml}$ Candida albicans, glabrata, or tropicalis on quantitative culture. In all 6 patients, the clinical diagnoses at admission included chronic aspiration. Greater than $10^{5} \mathrm{CFU} / \mathrm{ml}$ of a recognized bacterial pathogen (Streptococcus pneumoniae, Staphylococcus aureus, or Pseudomonas) or $>10^{6} \mathrm{CFU} / \mathrm{ml}$ of other 'normal respiratory flora' (Lactobacillus species) were present together with Candida spp. in every case. Blood cultures yielded Candida in 2 cases, and 1,3-beta-D glucan was $>500 \mathrm{ng} / \mathrm{mL}$ in 3 of 3 cases in which it was assayed. Since all patients were treated with anti-bacterial and anti-fungal drugs, no inference about etiology can be derived from therapeutic response.

Conclusions: Candida spp. together with a recognized bacterial pathogen or normal respiratory flora may contribute to the cause of CAP in patients who chronically aspirate.

Keywords: Pneumonia, Candida, Fungal pneumonia

\section{Background}

A standard teaching amongst infectious disease specialists is that pneumonia due to Candida species is a "very rare event" [1]. These organisms regularly colonize the mouth, and their numbers can increase if antibiotics are given. When yeast forms are seen on Gram stain and Candida are grown in sputum cultures, they are generally dismissed as oropharyngeal contaminants from colonizing organisms.

\footnotetext{
*Correspondence: Daniel.Musher@va.gov; danielmusher1@gmail.com ${ }^{1}$ Baylor College of Medicine, Houston, TX, USA

${ }^{2}$ Michael E. DeBakey Veterans Affairs Medical Center, Infectious Disease Section, Room 4B-370, VA Medical Center, Houston, TX 77030, USA
}

However, in severely immunocompromised patients, Candida spp. is known to invade locally causing thrush or, occasionally, pneumonia [1-5].

Definitive diagnosis of Candida pneumonia requires visualization of invasive Candida forms in the lung parenchyma. Autopsy series from large groups of immunosuppressed patients have documented the infrequent occurrence of Candida pneumonia [3-5]. Recent studies, however, have given more attention to a possible pathogenic role in pneumonia for Candida in combination with bacterial pathogens [6-9].

(c) The Author(s). 2021 Open Access This article is licensed under a Creative Commons Attribution 4.0 International License, which permits use, sharing, adaptation, distribution and reproduction in any medium or format, as long as you give appropriate credit to the original author(s) and the source, provide a link to the Creative Commons licence, and indicate if changes were made. The images or other third party material in this article are included in the article's Creative Commons licence, unless indicated otherwise in a credit line to the material. If material is not included in the article's Creative Commons licence and your intended use is not permitted by statutory regulation or exceeds the permitted use, you will need to obtain permission directly from the copyright holder. To view a copy of this licence, visit http://creativecommons.org/licenses/by/4.0/. 
In the course of a prospective observational study that documented an important role for normal respiratory flora as the cause of community acquired pneumonia (CAP) [10], we observed a surprising number of patients in whom Candida appeared to be playing a contributory role. In each case, chronic aspiration had been identified as a possible cause in the admitting history. In the present paper, we describe the clinical and microbiologic features of these and subsequent cases and propose that Candida, together with recognized bacterial pathogens or so-called normal respiratory flora, contributes to CAP more commonly than is generally believed, particularly in patients with a history of chronic aspiration.

\section{Methods}

\section{Study design}

Cases were identified during a prospective study of a convenience sample of patients admitted to the Michael E. DeBakey VA Medical Center between September 1, 2017 and January 31, 2020. On days selected for study, we examined Gram stains of all sputum samples that had been submitted to the clinical microbiology laboratory in the preceding $24 \mathrm{~h}$ without first reviewing the medical record. For every sputum categorized as highquality (> 20 white blood cells (WBC) per epithelial cell, a more rigorous standard than is usually used [11]), we reviewed the medical record to identify patients who had been admitted from the community with a diagnosis of CAP and had submitted the sputum sample within $16 \mathrm{~h}$ of antibiotic initiation. The diagnosis of CAP was verified based on the presence of a newly recognized pulmonary infiltrate and at least two of the following findings: subjective or objective fever; increased cough, sputum production or shortness of breath; pleuritic chest pain, rales, or confusion. Patients who had received antibiotics before hospitalization were excluded.

\section{Microbiology}

Methods for quantifying bacteria and Candida in sputum were described previously [10]. Briefly, sputum was solubilized with $0.4 \% \mathrm{~N}$-acetyl cysteine, and ten-fold dilutions were made. Aliquots $(0.01 \mathrm{ml})$ were streaked on blood and chocolate agar and incubated for $24-28 \mathrm{~h}$ at $37^{\circ} \mathrm{C}$ in an atmosphere of $10 \% \mathrm{O}_{2}$ and $5 \% \mathrm{CO}_{2}$. WBC in solubilized sputum were quantified using a hemocytometer. The numbers of bacteria and Candida per $\mathrm{ml}$ sputum were calculated. Speciation was by conventional means and confirmed using MALDI-TOF.

\section{Case definitions}

Our predetermined criterion for determining an etiologic role for a recognized bacterial pathogen, such as Streptococcus pneumoniae, Haemophilus influenzae, Staphylococcus aureus, or Pseudomonas aeruginosa, was the finding of $>10^{5} \mathrm{CFU} / \mathrm{ml}$ in a high-quality sputum sample [10, 12-15]. To designate an etiologic role for Candida spp., we used more stringent criteria, as we have done for organisms that are usually reported as "normal respiratory flora" such as as viridans streptococci, Corynebacteria, or Lactobacillus [10, 16]: (1) Microscopic examination of Gram-stained sputum showed large numbers of yeast forms, including some within polymorphonuclear leukocytes; and (2) quantitative culture demonstrated $>10^{6}$ CFU Candida spp. per $\mathrm{ml}$ with or without other bacteria in numbers that met the above-stated criteria. In this observational study, laboratory studies, in addition to blood counts, usual blood chemistries, routine sputum and blood cultures, PCR on a nasopharyngeal swab for respiratory viruses, plasma procalcitonin, sputum WBC counts, and serum 1,3 -beta-D glucan were done in a variable number of patients.

\section{Results \\ Clinical findings}

Six of 154 (3.9\%) patients hospitalized for CAP had sputum samples that, based on the above microbiologic criteria, suggested a contributory etiologic role for Candida spp. The median age was 73 (range: 59 to 82). In every case the admitting history noted factors associated with aspiration, and aspiration pneumonia was included as a possible diagnosis (Table). Importantly, these cases were not selected because of a history suggesting aspiration but were identified by sputum criteria, after which the historical information at admission was determined from the medical record.

Patients identified in this fashion had a high rate of comorbid conditions: the average Charlson Comorbidity Index was 8 for patients with Candida pneumonia compared to 5.5 for patients with CAP due to other respiratory pathogens ( $t$-test, $p=0.02)$ [10]. Two had wellcontrolled diabetes mellitus (hemoglobin A1c $\leq 6.7$ ) and none was receiving glucocorticosteroids prior to admission. One of the patients was admitted directly from a hospice facility (case 5); the others were admitted from the community. None had intravenous lines at the time of admission, but 3 were receiving nutrition via percutaneous endoscopic gastrostomy tube. There was no documentation of antibiotics given in 8 weeks leading up to admission. In all cases, physical examination disclosed rales, and chest radiographs showed bilateral opacities. Thrush was noted in case 4 (Table). Computed tomography $(\mathrm{CT})$ of the chest was performed in cases 4,5 , and 6. In all three, CT demonstrated bilateral patchy opacities consistent with multifocal pneumonia. Bronchiectasis was not noted. The peripheral WBC count at admission was elevated $\left(>10,500 / \mathrm{mm}^{3}\right)$ in 4 cases. The median WBC count was $16,550 / \mathrm{mm}^{3}$, compared to 
median WBC counts of $12,800 / \mathrm{mm}^{3}$ in pneumococcal and $12,200 / \mathrm{mm}^{3}$ in Haemophilus pneumonia [17]. Plasma procalcitonin exceeded $0.5 \mathrm{ng} / \mathrm{ml}$ in 3 of 5 patients in whom it was tested.

\section{Microbiologic findings}

In all 6 cases, large numbers of yeast forms were readily apparent on sputum Gram stain; 4-14\% of polymorphonuclear cells (PMNs) contained intracellular yeast, and pseudohyphae were seen in 5 cases (Table, Figs. 1 and 2). These patients all had $>10^{6} \mathrm{CFU} / \mathrm{ml}$ of Candida spp. in their sputum: 3 with C. albicans, 2 with C. glabrata, and 2 with $C$. tropicalis (one specimen had both $C$. tropicalis and C. glabrata). However, no case met microbiologic criteria for pneumonia due to Candida alone: quantitative sputum cultures yielded $>10^{5} \mathrm{CFU} / \mathrm{ml}$ of a recognized bacterial pathogen (S. pneumoniae, H. influenzae, S. aureus, and/or $P$. aeruginosa) in 3 cases and $>10^{6} \mathrm{CFU} / \mathrm{ml}$ normal respiratory flora (Lactobacillus) in the other 3 cases. Gram stain and quantitative cultures yielded consistent results in all but 1 case in which many Gram positive cocci were seen but not cultured; we regarded these as probable anaerobic organisms [10]. The median number of WBC in sputum was $1.3 \times 10^{7}$ per ml. An assay for serum 1,3-beta-D glucan was performed in 3 cases, and the level was $>500 \mathrm{ng} / \mathrm{ml}$ in all 3 . Blood cultures, done in 6 patients, yielded C. glabrata in one case, but that patient also had C. glabrata in the urine and C. albicans in the sputum. PCR for respiratory viruses was positive in 2 of 3 cases in which it was done.

\section{Treatment}

Anti-bacterial and anti-fungal treatments were given in all cases (fluconazole in 3 and micafungin in 3) (Table 1). Two patients ultimately had care withdrawn; the other 4 recovered. Mortality in these 6 patients was 33.3\% during admission and $66.7 \%$ at 1 year.

\section{Discussion}

In this prospective, observational study, we describe 6 of 154 patients in whom Candida spp. appeared to play a contributory etiologic role in CAP. These patients shared clinical and laboratory features that distinguished them from usual CAP patients. (1) All had conditions that suggested a diagnosis of aspiration pneumonia to their admitting physicians. (2) The Charlson Comorbidity Index was substantially higher than is usual for CAP patients. (3) Gram stains of sputum showed large numbers of yeast forms, many within PMNs; (4) Quantitative cultures yielded $>10^{6} \mathrm{CFU}$ Candida per ml sputum. (5) Pseudohyphae were seen in 5 of 6 cases. (6) 1,3-beta-Dglucan was strongly positive in the 3 patients in whom it was tested.

Importantly, a Candida spp. was never detected as a sole infecting organism. Greater than $10^{5} \mathrm{CFU} / \mathrm{ml}$ of recognized bacterial pathogens or $>10^{6} \mathrm{CFU} / \mathrm{ml}$ of bacteria generally identified as 'normal respiratory flora' were also present in every case. Viral PCR was positive in 2 of 3 cases in which it was tested. In fact, 3 patients appeared to be infected with more than one Candida spp. In Case 6, two different Candida spp. were identified in sputum. In Cases 1 and 4, one Candida spp. was grown

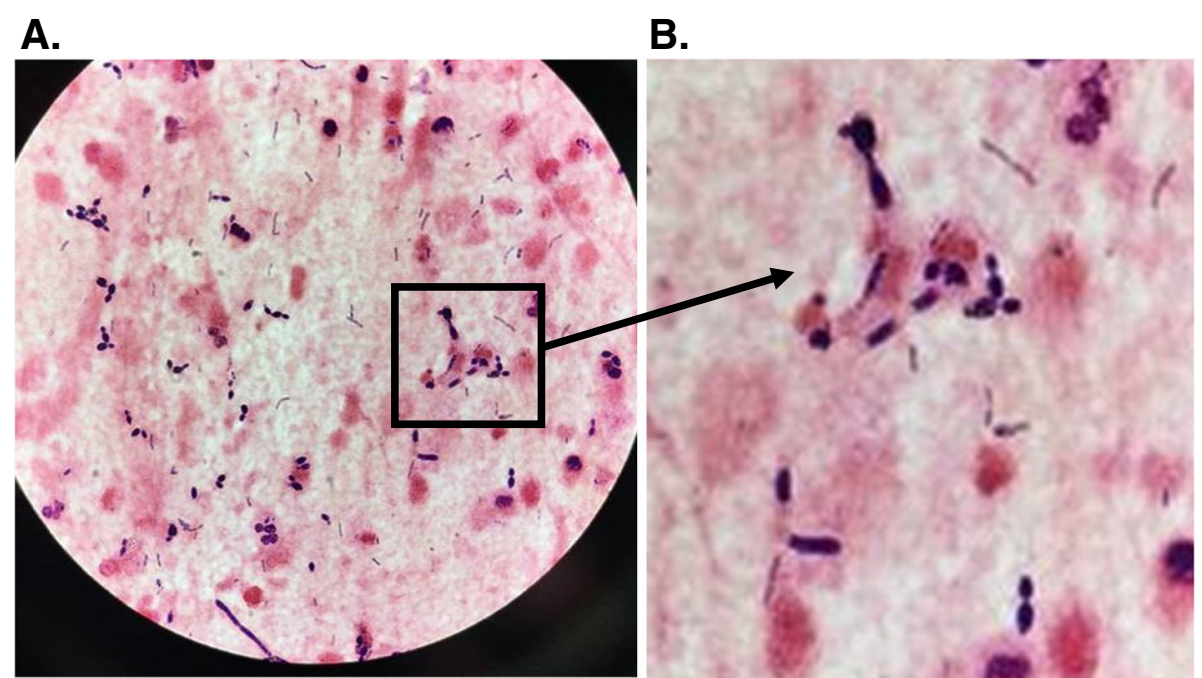

Fig. 1 A. Sputum Gram stain (case 5) at 1000x magnification showing polymorphonuclear leukocytes and monocytes. The red background indicates protein in secretions. Absence of epithelial cells indicates absence of contamination by oropharyngeal secretions. Large numbers of budding yeast forms are seen, many of which are intracellular, with some pseudohyphae. Many fine Gram positive rods are also seen. B. Enlargement of boxed area shows what appear to be deteriorating pseudohyphae. Culture yielded $4 \times 10^{6}$ Candida tropicalis and $1.6 \times 10^{8}$ Lactobacillus gasseri 


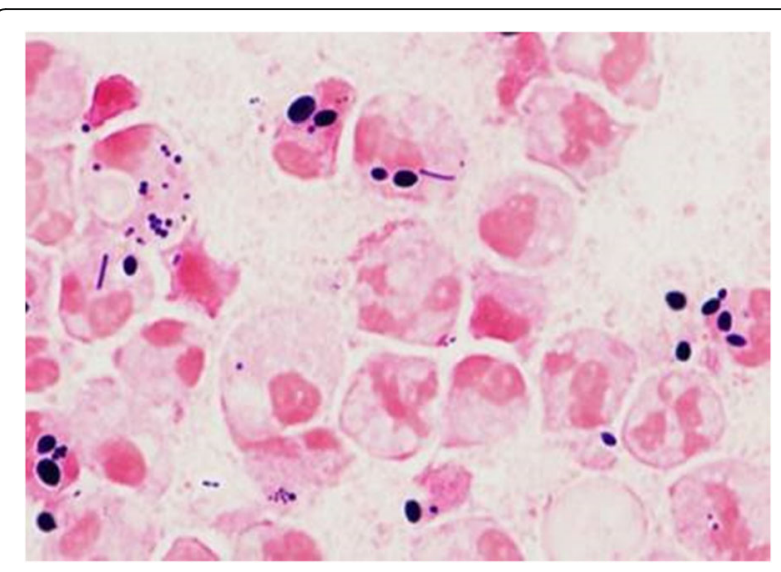

Fig. 2 Sputum Gram stain (case 4) at 1000x magnification, showing many WBC with intracellular yeast and Gram positive cocci. Culture yielded $2 \times 10^{7}$ C. albicans, $5 \times 10^{7}$ S. aureus, and $4 \times 10^{7}$

S. pneumoniae

from blood and another was identified in the sputum. This seeming discrepancy results from the fact that only 1 or 2 colonies are selected for identification by MALDITOF. In young cultures, colonies of $C$. albicans and $C$. glabrata look alike, and the one growing in the blood might simply have been missed in the sputum. This explanation is supported by the finding of pseudohyphae in sputum from Case 1; the patient was infected with both, but only C. glabrata, which does not make pseudohyphae, was identified in sputum, whereas the blood culture yielded $C$. albicans. While these results do not prove that Candida spp. alone causes CAP, they suggest that Candida spp. may be a contributory cause of CAP, especially in patients who have a history of chronic aspiration.

Evidence opposing an etioloic role for Candida spp. in CAP has led to the teaching that the finding of Candida spp. in sputum culture simply reflects contamination by oropharyngeal colonization. Candida spp. regularly colonize the upper respiratory tract, with higher rates of colonization in sicker patients. An early study reported the presence of Candida in the sputum in increasing proportions of medical students, hospital employees, and patients, respectively [18]. Sputum cultures of 55\% of medical inpatients yielded Candida; quantitative cultures were not done and the quality of the sputum sample was not addressed [18]. Rello et al reported that, in 28 adults with suspected pneumonia and positive sputum cultures for Candida spp., protected brush bronchoscopic specimens yielded $>10^{3} \mathrm{CFU} / \mathrm{ml}$ Candida spp. in 24 cases, but most of these were regarded as contaminants [19]. Of 135 autopsies done on patients with evidence of pneumonia, respiratory samples from 77 had been positive for Candida spp., but none had histologic evidence of Candida pneumonia [20]. Conversely, most patients with histologic evidence of Candida pneumonia on lung biopsy did not grow Candida on premortem cultures [21]. In contrast to our work, only one of these studies quantitated Candida, and used a cutoff of $10^{3} \mathrm{CFU} / \mathrm{ml}$, lower than our cutoff of $10^{6} \mathrm{CFU} / \mathrm{ml}$.

In patients with CAP, sputum is the expectorated material that has collected in alveoli, including plasma, PMNs, and microbes. A sample that shows pure, or nearly pure PMNs and large numbers of microbial forms should reflect alveolar exudate. We have used these criteria in the past to show that non-typeable Haemophilus influenzae [13], Moraxella catarrhalis [10, 22], Corynebacterium [16] and other bacteria generally dismissed by microbiology laboratories as 'normal respiratory flora' [10] all may cause pneumonia. To our knowledge, no one has previously reported Gram stains and quantitative cultures of Candida in high-quality sputum samples, while requiring large numbers of organisms including intracellular forms and pseudohyphae to be seen microscopically and $>10^{6} \mathrm{CFU} / \mathrm{ml}$ to be present. In the present study, the high quality of the sputum samples was shown by the presence of $1.3 \times 10^{7} \mathrm{WBC}$ per ml (median value) and the absence of epithelial cells in microscopic fields at $1000 \mathrm{x}$ magnification. We identified intracellular yeast forms within PMNs in all samples and pseudohyphae in 5 samples, further supporting a pathogenic role for Candida.

Some of these approaches have been utilized in intubated patients with suspected ventilator-associated pneumonia (VAP). In one study, the presence of intracellular organisms in at least $2 \%$ of cells had a sensitivity of $84 \%$ and a specificity of $80 \%$ for VAP [23]. Using a cutoff of $5 \%$ intracellular organisms, Torres et al, found a positive predictive value of $75 \%$ for diagnosing VAP using protected bronchoalveolar lavage [24]. In another study, a cutoff of $7 \%$ was $97 \%$ specific for diagnosing VAP [25]. We observed intracellular yeast in every sputum sample.

A limitation of the current study is the absence of a diagnosis of Candida pneumonia by lung biopsy. Without histologic evidence of invasion of yeast into lung parenchyma, Candida pneumonia cannot be diagnosed with certainty. However, most etiologic diagnoses of pneumonia are presumptive, unless organisms are also grown from a normally sterile site. Additionally, not all patients had the same evaluation including 1,3-beta-Dglucan, procalcitonin, and viral PCR. Treatment decisions were made by managing clinicians; all patients received both antibacterial and antifungal agents, and care was withdrawn in 2 cases, making it impossible to determine which treatments were beneficial.

The present study provides evidence suggesting that, in patients who have risk factors for chronic aspiration Candida spp. plays a contributory role in the etiology of 


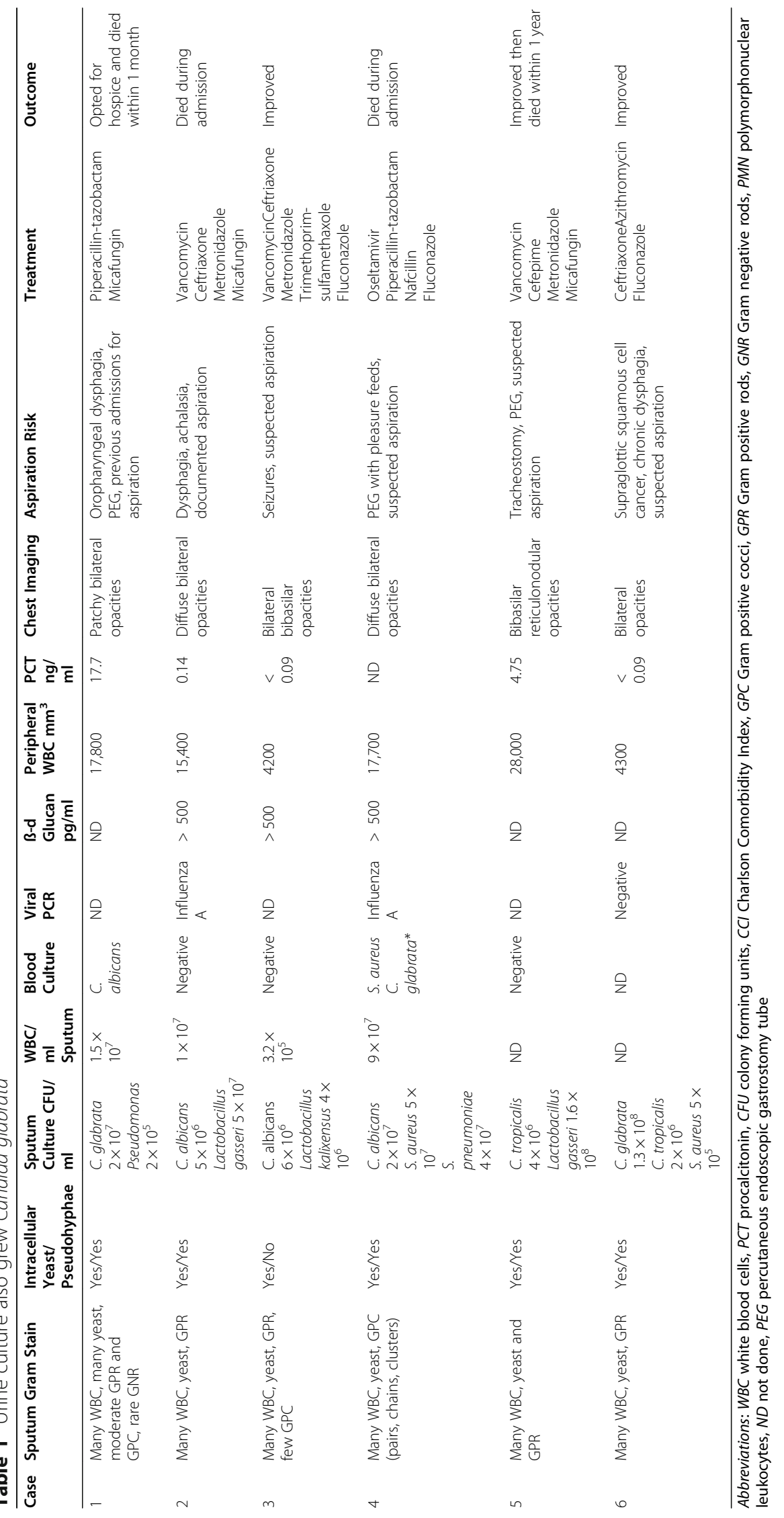


CAP. We found that patients with CAP who had large numbers of Candida in a high-quality sputum sample all had a history consistent with aspiration, and in each case the infection was polymicrobial. These findings support the principle that a sufficient inoculum of organisms of low virulence into the lower respiratory tract may suffice to cause pneumonia.

The subject of yeast-bacteria interaction has been extensively studied. Roux et al have shown in rats that infection with Candida facilitates bacterial infection by interfering with the function of alveolar macrophages $[6,8]$, and Neely et al [26] showed that bacterial colonization of burn wounds rendered Candida more invasive [7]. In critically ill patients, the presence of Candida in sputum cultures has been associated with increased risk of VAP due to Pseudomonas aeruginosa [27].

In conclusion, by examining sputum samples submitted for Gram stain and culture, we found that, of 154 high-quality specimens ( $>20 \mathrm{WBC}$ per epithelial cell) from patients who were hospitalized with a diagnosis of CAP, 6 contained large numbers of intra- and extracellular yeast forms. Admitting physicians, unaware of microscopic findings, diagnosed chronic aspiration in all cases. Quantitative cultures revealed $>10^{6} \mathrm{CFU}$ Candida spp. per ml. Sputum from 5 samples showed pseudohyphae. One patient had candidemia, and in 3 whose serum was assayed for 1,3-beta-D-glucan, the level was markedly elevated. In every case bacterial coinfection was present and 2 patients had viral coinfection. These findings suggest that Candida spp. may play a contributory role in the etiology of CAP in patients who have a history of chronic aspiration. Future studies are needed to address whether patients with this constellation of findings benefit from antifungal therapy.

\section{Abbreviations \\ CAP: Community-acquired pneumonia; WBC: White blood cells; CFU: Colony- forming units; PMN: Polymorphonuclear cells; VAP: Ventilator-associated pneumonia}

\section{Authors' contributions}

BJM analyzed and interpreted all data and was the primary writer of the manuscript. DMM collected, analyzed, and interpreted all data and contributed to the writing of the manuscript. The author(s) read and approved the final manuscript.

\section{Funding}

None.

\section{Availability of data and materials}

The datasets used and/or analysed during the current study are available from the corresponding author on reasonable request.

\section{Declarations}

\section{Ethics approval and consent to participate}

Protocol H-29468, Community-acquired pneumonia, approved by the Insitutional Review Board, Baylor College of Medicine.
Consent for publication

Pending.

\section{Competing interests}

The authors declare that they have no competing interests.

Received: 5 January 2021 Accepted: 17 May 2021

Published online: 05 July 2021

\section{References}

1. Lionakis MS, Edwards JE Jr. Candida species. In: Bennett JE, Doliin R, Blaser MJ, editors. Mandell, Duglas, and Bennett's Principles and Pracice of Infectious Diseases. Philadelphia: Elsevier; 2020. p. 3087-102.

2. Singh A, Verma R, Murari A, Agrawal A. Oral candidiasis: an overview. J Oral Maxillofac Pathol. 2014;18(Suppl 1):S81-5. https://doi.org/10.4103/0973-02 9X.141325.

3. Masur H, Rosen PP, Armstrong D. Pulmonary disease caused by Candida species. Am J Med. 1977;63(6):914-25. https://doi.org/10.1016/0002-9343 (77) $90546-0$

4. Mohsenifar Z, Chopra SK, Johnson BL, Simmons DH. Candida pneumonia: experience with 20 patients. West J Med. 1979:131(3):196-200.

5. Haron E, Vartivarian S, Anaissie E, Dekmezian R, Bodey GP. Primary Candida pneumonia. Experience at a large cancer center and review of the literature. Medicine (Baltimore). 1993;72(3):137-42.

6. Roux D, Gaudry S, Dreyfuss D, El-Benna J, de Prost N, Denamur E, et al. Candida albicans impairs macrophage function and facilitates Pseudomonas aeruginosa pneumonia in rat. Crit Care Med. 2009;37(3):1062-7. https://doi. org/10.1097/CCM.0b013e31819629d2

7. Peleg AY, Hogan DA, Mylonakis E. Medically important bacterial-fungal interactions. Nat Rev Microbiol. 2010;8(5):340-9. https://doi.org/10.1038/ nrmicro2313.

8. Roux D, Gaudry S, Khoy-Ear L, Aloulou M, Phillips-Houlbraca M, Bex J, et al. Airway fungal colonization compromises the immune system allowing bacterial pneumonia to prevail. Crit Care Med. 2013;41(9):e191-9. https://doi. org/10.1097/CCM.0b013e31828a25d6.

9. Pendleton KM, Huffnagle GB, Dickson RP. The significance of Candida in the human respiratory tract: our evolving understanding. Pathog Dis. 2017;75(3). https://doi.org/10.1093/femspd/ftx029.

10. Musher DM, Jesudasen SS, Barwatt JW, Cohen DN, Moss BJ, RodriguezBarradas MC. Normal Respiratory Flora as a Cause of Community-Acquired Pneumonia. Open Forum Infect Dis. 2020;7(9):ofaa307.

11. Murray PR, Washington JA II. Microscopic and bacteriologic analysis of expectorated sputum. Mayo Clin Proc. 1975;50(6):339-44.

12. Thorsteinsson SB, Musher DM, Fagan T. The diagnostic value of sputum culture in acute pneumonia. JAMA. 1975;233(8):894-5. https://doi.org/10.1 001/jama.1975.03260080056024.

13. Musher DM, Kubitschek KR, Crennan J, Baughn RE. Pneumonia and acute febrile tracheobronchitis due to Haemophilus influenzae. Ann Intern Med. 1983;99(4):444-50. https://doi.org/10.7326/0003-4819-99-4-444.

14. Jordan GW, Wong GA, Hoeprich PD. Bacteriology of the lower respiratory tract as determined by fiber-optic bronchoscopy and transtracheal aspiration. J Infect Dis. 1976;134(5):428-35. https://doi.org/10.1093/ infdis/134.5.428.

15. Gadsby NJ, Russell CD, McHugh MP, Mark H, Conway Morris A, Laurenson IF, et al. Comprehensive molecular testing for respiratory pathogens in community-acquired pneumonia. Clin Infect Dis. 2016;62(7):817-23. https:// doi.org/10.1093/cid/civ1214.

16. Yang K, Kruse RL, Lin WV, Musher DM. Corynebacteria as a cause of pulmonary infection: a case series and literature review. Pneumonia (Nathan). 2018;10(1):10. https://doi.org/10.1186/s41479-018-0054-5.

17. Shoar S, Centeno FH, Musher DM. Clinical Features and Outcomes of Community-Acquired Pneumonia Caused by Haemophilus Influenza. Open Forum Infect Dis. 2021;8(4):ofaa622.

18. Baum GL. The significance of Candida albicans in human sputum. N Engl J Med. 1960;263(2):70-3. https://doi.org/10.1056/NEJM196007142630204.

19. Rello J, Esandi ME, Diaz E, Mariscal D, Gallego M, Valles J. The role of Candida sp isolated from bronchoscopic samples in nonneutropenic patients. Chest. 1998;114(1):146-9. https://doi.org/10.1378/chest.114.1.146.

20. Meersseman W, Lagrou K, Spriet I, Maertens J, Verbeken E, Peetermans WE, et al. Significance of the isolation of Candida species from airway samples 
in critically ill patients: a prospective, autopsy study. Intensive Care Med. 2009;35(9):1526-31. https://doi.org/10.1007/s00134-009-1482-8.

21. el-Ebiary M, Torres A, Fabregas N, de la Bellacasa JP, Gonzalez J, Ramirez J, et al. Significance of the isolation of Candida species from respiratory samples in critically ill, non-neutropenic patients. An immediate postmortem histologic study. Am J Respir Crit Care Med. 1997;156(2 Pt 1): 583-90.

22. Wallace RJ Jr, Musher DM. In honor of Dr. Sarah Branham, a star is born. The realization of Branhamella catarrhalis as a respiratory pathogen. Chest. 1986; 90(3):447-50.

23. Allaouchiche B, Jaumain H, Dumontet C, Motin J. Early diagnosis of ventilator-associated pneumonia. Is it possible to define a cutoff value of infected cells in BAL fluid? Chest. 1996;110(6):1558-65.

24. Torres A, El-Ebiary M, Fabregas N, Gonzalez J, de la Bellacasa JP, Hernandez $C$, et al. Value of intracellular bacteria detection in the diagnosis of ventilator associated pneumonia. Thorax. 1996;51(4):378-84. https://doi. org/10.1136/thx.51.4.378.

25. Brasel KJ, Allen B, Edmiston C, Weigelt JA. Correlation of intracellular organisms with quantitative endotracheal aspirate. J Trauma. 2003;54(1): 141-4; discussion 144-6. https://doi.org/10.1097/00005373-200301000-00017.

26. Neely AN, Law EJ, Holder IA. Increased susceptibility to lethal Candida infections in burned mice preinfected with Pseudomonas aeruginosa or pretreated with proteolytic enzymes. Infect Immun. 1986;52(1):200-4. https://doi.org/10.1128/IAl.52.1.200-204.1986.

27. Azoulay E, Timsit JF, Tafflet M, de Lassence A, Darmon M, Zahar JR, et al. Candida colonization of the respiratory tract and subsequent pseudomonas ventilator-associated pneumonia. Chest. 2006;129(1):110-7. https://doi.org/1 0.1378/chest.129.1.110

\section{Publisher's Note}

Springer Nature remains neutral with regard to jurisdictional claims in published maps and institutional affiliations.

Ready to submit your research? Choose BMC and benefit from:

- fast, convenient online submission

- thorough peer review by experienced researchers in your field

- rapid publication on acceptance

- support for research data, including large and complex data types

- gold Open Access which fosters wider collaboration and increased citations

- maximum visibility for your research: over $100 \mathrm{M}$ website views per year

At BMC, research is always in progress.

Learn more biomedcentral.com/submissions 